\title{
Development of Chemical Principles Class XI Senior High School Based on the Project in the Material Solubility and Solubility
}

\author{
Bajoka Nainggolan $^{1}$, Yuni Mantana Nainggolan ${ }^{2}$, and Wesly Hutabarat ${ }^{3}$ \\ \{nainggolanbajoka@gmail.com ${ }^{1}$ \} \\ Department of Chemistry, Universitas Negeri Medan ${ }^{1,2,3}$
}

\begin{abstract}
The investigation was a research and development using ADDIE method which aims to get a standardized project-based chemical practicum guidedbook on solubility and solubility (Ksp) products. Population of the study was all ofthe Unimed chemistry lecturers, chemistry teachers and students of grade XI IPA 14 Medan, and all of the practical guide books publishedin Medan. Sampling was selected by purposive sampling technique which consists of 3 chemical practicum guided bookspublished by three companies called A, B and C chemistry laboratory guide books; 2 chemistry lecturers; 2 chemistry teachers; and grade XI IPA-1 as experiment group1 and IPA-4 as experimental group 2. Average standardized scores of practicum guided books developed $=3.78$ was higher than the practicum guidedbooks $\mathrm{A}=3.14 ; \mathrm{B}=3,32 ;$ and $\mathrm{C}=3.11$ respectively. Percentage of normalized gain test of the practicum guided book developed in the experimental group 1 was higher than the experimental group 2 i.e $88.00 \%>$ $80.00 \%$. Post-test scores on the right side at $\alpha=0.05$, obtained t-count. $=6.4>\mathrm{t}$-tab. $=$ 1.67. This shows that the project-based chemistry practical guided book developed is in accordance with BSNP standards and can be used in high schools..
\end{abstract}

Keywords: Practical Guidance, project-based-learning, solubility and solubility results, ADDIE method.

\section{Introduction}

Chemistry is one of the subjects at the senior high school level that is taught through Scientific Method. A number of students have difficulty in learning chemistry because the concepts are abstract (Tatli and Alipasa,2012). Scientifically chemistry is experimental science, which means that in studying chemistry it is not recommended to deliver by asking the students to listen and read, but they are encouraged to do learning by doing in laboratory class in order to build students' knowledge about the material being studied. One of the obstacles experienced by teachers in practicum implementation at schools, is the unavailability of chemistry practicum guided books that can be used to motivate the students to achieve learning objectives (Tuyrus, 2010). Generally laboratory experiments which are integrated with chemistry subject matter will enable students to build their own experiences with concrete materials(Tatli and Alipasa, 2013). Constraints that are often experienced by teachers in the practicum at schools are due to limited equipment, time, and the unavailability of the chemistry lab guided books that can direct students in doing practical works (Tuysuz, 2010). Sakri et.al., (2014) reported that an integrated learning approach in Semi-Small Scale 
(SSSEs) -based experiments can significantly improve student learning outcomes of grade XII. Kalek and Lee (2012), found that integrated project-based learning practices can change students' understanding of abstract chemical concepts that are considered difficult, become easy to understand and can significantly improve student chemistry learning outcomes. Shi-Jer Lou et al., (2012), integrated learning practices in organic chemistry

experiments using three forms of multimedia teaching materials, inthe form of static images, video, and animation, can significantly improve student chemistry learning outcomes.

In learning integrated with practicum required module in the form of a module according to BSNP standard. Teaching materials in the form of module that meet the standard eligibility criteria of BSNP, facilitate the students in obtaining a picture of the purpose, benefits and process activities that will be practiced. Teaching materials in the form of a good module should be arranged systematically, interestingly, clearly, can be used by students independently anytime according to the needs of students (Anwar, 2010). In the development of teaching materials in the form of textbooks and modules, there are a number of methods one of which is ADDIE (Analysis, Design, Development, Implementation, and Evaluations) (Sugiyono, 2010

In Project Based Learning environments, students learn primarily by constructing knowledge and making meaning through iterative processes of questioning, active learning, sharing, and reflection. It service learning emphasizes educational opportunities that are interdisciplinary, student-centered, collaborative, and integrated with real-world issues and practices (Chiang and Lee, 2016). PjBL also involves students' knowledge and skills in solving real life-reflective problems and focuses on organizing independent learning in projects (Robinson and Vega, 2013).

Considering the importance of chemistry in the learning process of integrated practice to improve the students' scientific skills, it is necessary to develop textbooks in the form of an innovative chemistry module that meets the standard criteria of BSNP for high school / MA students, and as a textbook of high school chemistry for teachers chemistry. Based on the description above, then conducted research: "Development Module Chemistry Class XI SMA Based Project on Solubility and Solubility Product".

\section{Theoritical Framework}

Method used is a Research and Development ( R \& D) with a model ADDIE modified model development Sugiyono (2010), consists of the analysis, design,development, implementation, andevaluation. The development stages of ADDIE are presented as shown below. 


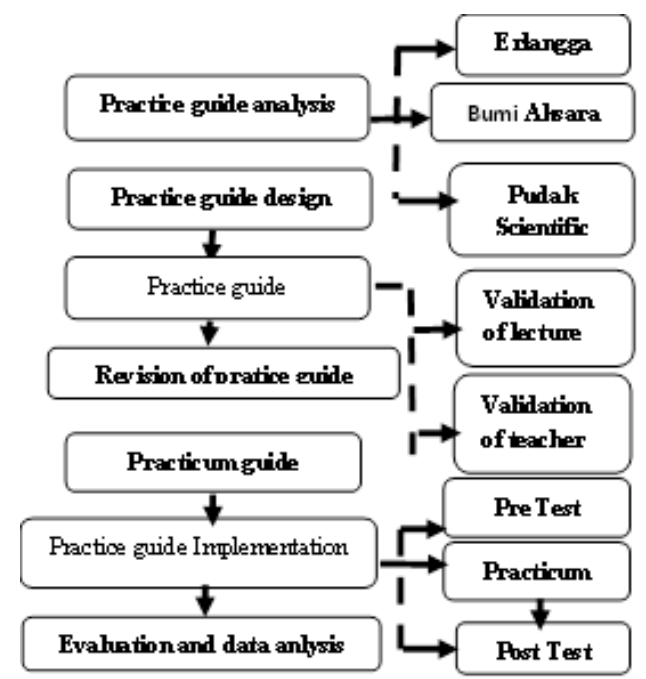

Fig 2.1. Research Procedures and Development of Chemistry Practicum Guidance for Class XI Science High School with ADDIE method

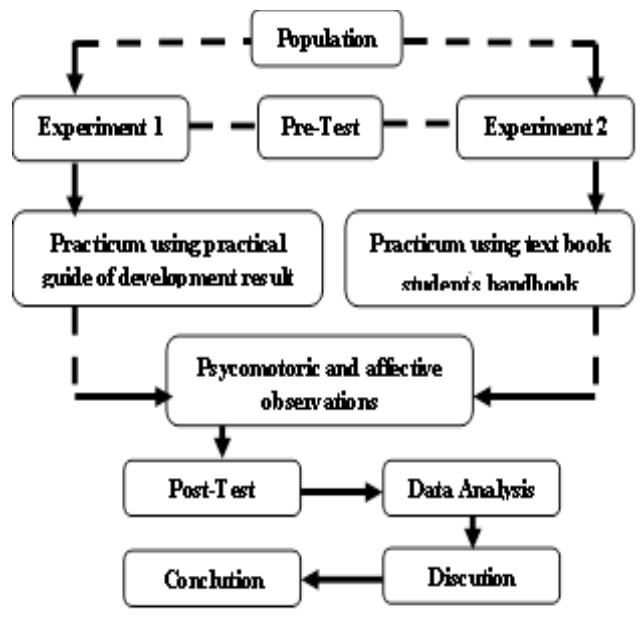

Fig 2.2. Research Prosedure

\subsection{Stage Module Analysis}

Before conducting the research, firstly done the analysis of syllabus, and analysis of module SMA circulating Medan, ie module class XI SMA publisher Pudak Scientific (A), Bumi Aksara (B ), and Erlangga (C).

\subsection{Stage Module Design}

After analyzing the chemistry module, the researcher drafted the draft which will be developed to module the project-based innovative practice by taking note of the advantages and disadvantages of the chemistry lab work that has been analyzed. 


\subsection{Stage Module Development}

At this stage of development, the researcher makes the module become the reference source in developing and developing innovative project-based module on Solubility and solubility product (Ksp) material in accordance with the BSNP assessment standard.

\subsection{Stage Implementation Module Chemistry developed}

Implementation module chemistry that has been developed was conducted in the experiment class . Done the first Pre-test is, then continued learning integrated practice after that done post-test.

\subsection{Module and Data Analysis}

At this stage, an assessment and analysis of student learning outcomes. Qualitative data in the form of questionnaire obtained from the validation team of 2 lecturers of chemistry Unimed and 2 chemistry teachers SMA Negeri 4 Medan.

Quantitative data were obtained through pre-test and post-test to the students. Student activity data was obtained through observation of 4 observers during the samples treatment.

The eligibility analysis of the module uses theformula:

Where,

$$
\mathrm{X}=\Sigma \mathrm{X} / \mathrm{n}
$$

$\mathrm{X}^{-}=$average value

$\Sigma \mathrm{X}=$ number of validator assessment answers,

$\mathrm{n}=$ number of validators.

Normality test with Chi-Square at the level of real $\alpha=0,05$ with criterion Chi Square $\left(\mathrm{X}_{2}\right)_{\text {count }}<\left(\mathrm{X}_{2}\right)_{\text {table }}$ hence stated normal distribution

The validity of the $F_{\text {count }}=$ (the greatest variance)/(the smallest variance) if $F_{\text {count }}>F_{\text {table }}$ of data homogeneous.

Percent increase learning outcomes calculated using the formula "g" factor (gainscore normalized).

The formula "g" factor used is $\% \mathrm{~g}=($ score post-test - score pre-test)/(maximum score- pretest score $) \times 100 \%$

Hypothesis test using test formula for two sample groups with one-party $t_{\text {test. }}$

$\mathrm{X}^{\overline{1}}=$ student learning outcomes 1

$$
\mathrm{t}_{\text {count }}=\frac{\overline{\mathrm{X}}_{1}-\overline{\mathrm{X}}_{2}}{\sqrt{\frac{\mathrm{s}_{1}^{2}}{\mathrm{n}_{1}}+\frac{\mathrm{s}_{2}^{2}}{\mathrm{n}_{2}}}}
$$

$\mathrm{X} \overline{2}=$ student learning outcomes 2

$\mathrm{S}=$ Standard deviation

$\mathrm{n}=$ numbers of sample 


\section{Results And Discussion}

\subsection{Module Validated}

Analysis of the module A, B, and C based on BSNP obtainedindicators, it was found data as shown in the following table 1 .

Table 1.Analysis of Chemistry Module Published (A), (B), and (C)

\begin{tabular}{clccc}
\hline No & \multicolumn{1}{c}{ BSNP } & \multicolumn{2}{c}{ Mean scores of Teachers and Lecturers on the Module Published } \\
& Standard & A & B & C \\
\hline 1 & Eligibility of & 3.23 & 3.45 & 3,23 \\
& content & (moderately valid) & (valid) & (moderately valid) \\
2 & Eligibility of & 3.25 & 3.33 & 3.33 \\
& languages & (moderately valid) & (valid) & (valid) \\
3 & Eligibility of & 3.22 & 3.50 & 3.22 \\
& presentation & (moderately valid) & (valid) & (moderately valid) \\
4 & Eligibility of & 2.84 & 3.0 & 2.67 \\
& graffity & (moderately valid) & (relatively valid) & (relativelyvalid) \\
\hline
\end{tabular}

As shown in the Table 1 it is known that the average scores of teachers and lecturers on the chem. lab guided book A which met the BSNP standards, the eligibility of content, language eligibility, eligibility of presentation, and eligibility of grafifiti were classified asmoderately valid of 3,$23 ; 3.25 ; 3.25$; and relatively of 2.84 . The highly valid criteria ranges from 3,26to 4,00. It was found that the module of the chem..lab. guided book (A) does not meet the standard criteria according to the BSNP. It was also found that the eligibility of validity of module B classified as moderately valid with an average score of 3.0; while the content, language, and presentation eligibility wereclassifiedas highly valid with the average scores of $3.45 ; 3.33$ and 3.50 . It was found that the eligibility of graffiti of the Bumi Aksara module B does not meetthe standard criteriaof the BSNP. Analysis of the C module, published by Erlangga and it was found that the language eligibility scores of 3.33 was classified as moderately valid, meanwhile the content eligibility, presentation, and graffiti classified as moderately valid with the average scores of 3.233 .22 ; and 2.67 respectively. Therefore, the C module of the Erlangga does not meet the standard of the BSNP. The analysis of the chemistry module $\mathrm{A}, \mathrm{B}$, and $\mathrm{C}$ were presented in the following figure 3.1

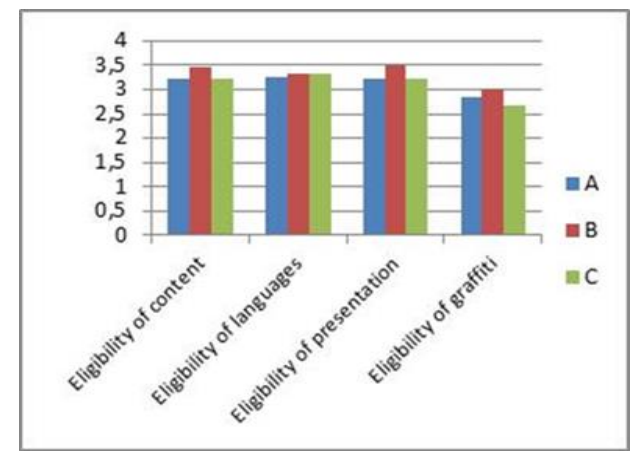

Fig 3.1. Diagram of the A, B and C Chemistry Lab Guided Books 


\section{Module Analized}

The chemistry module developed was analyzed and the result presented in the following Table 2.From Table 2 can be seen the average validator 2 chemistry teacher of SMA Negeri 14 Medan and 2 chemistry faculty lecturers FMIPA UNIMED to module the groundbreaking of project-based innovative chemicals developed for the eligibility of the contents of 3.95 and 3.95 respectively, 3.95 average; for the eligibility of languages 3.75 and 3.83, averaging 3.79 ; for eligibility of presentation of 3.56 and 3.72, averaging 3.64; and for the eligibility of 3,67 and 3,83 feats, an average of 3.75. This indicates that teachers and lecturers have given a positive opinion on the chemistry study material Solubility and solubility product (Ksp) that has been developed, is valid and no longer need revision. The average end score of the module chemistry that has been developed is 3.78, meaning that it is in accordance with the BSNP standard and feasible to be used in SMA / MA. The diagram of the result assessment of the chemical module that has been developed is as in the following Figure 4.1.

Table 2. Data Analysis of the Chemistry Module developed

\begin{tabular}{|c|c|c|c|c|c|}
\hline \multirow[t]{2}{*}{ No } & \multirow{2}{*}{$\begin{array}{l}\text { Criteria } \\
\text { BSNP }\end{array}$} & \multicolumn{2}{|c|}{$\begin{array}{c}\text { Average } \\
\text { assessment } \\
\text { Validator }\end{array}$} & \multirow[t]{2}{*}{ Average } & \multirow{2}{*}{$\begin{array}{c}\text { Criteria } \\
\text { validation }\end{array}$} \\
\hline & & $\begin{array}{c}\text { Teach } \\
\text { er }\end{array}$ & Lecturer & & \\
\hline 11 & $\begin{array}{l}\text { Eligibility } \\
\text { of content }\end{array}$ & 3.95 & 3.95 & 3.95 & $\begin{array}{l}\text { Valid and no } \\
\text { need revision }\end{array}$ \\
\hline 22 & $\begin{array}{l}\text { Eligibility } \\
\text { of } \\
\text { Language }\end{array}$ & 3.75 & 3.83 & 3.79 & $\begin{array}{c}\text { Valid and } \\
\text { unnecessary } \\
\text { revision }\end{array}$ \\
\hline 33 & $\begin{array}{l}\text { Eligibility } \\
\text { of } \\
\text { presentation }\end{array}$ & 3.56 & 3.72 & 3.64 & $\begin{array}{l}\text { Valid and no } \\
\text { need for } \\
\text { revision }\end{array}$ \\
\hline 44 & $\begin{array}{l}\text { Eligibility } \\
\text { of graffity }\end{array}$ & 3.67 & 3.83 & 3.75 & $\begin{array}{l}\text { Valid and no } \\
\text { revision }\end{array}$ \\
\hline & 2. & & 3. & 3.78 & $\begin{array}{l}\text { According to } \\
\text { BSNP } \\
\text { Standard }\end{array}$ \\
\hline
\end{tabular}




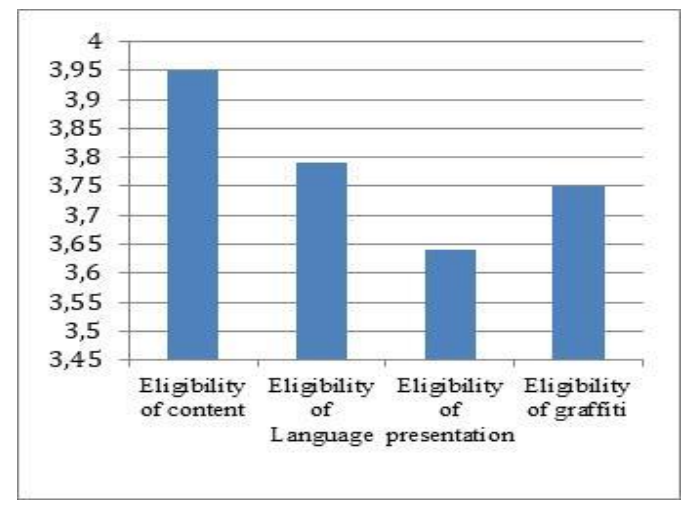

Fig 4.1. Diagram Assessment of the Chemistry ModuleDeveloped

The qualities of module chemistry that has bee developed are presented as in the following table.

Table 3. Quality of the ChemistryModule Developed

\begin{tabular}{|c|c|}
\hline $\begin{array}{c}\text { Standards of } \\
\text { BSNP }\end{array}$ & $\begin{array}{c}\text { Quality Module Chemistry That Has Been } \\
\text { Developed }\end{array}$ \\
\hline $\begin{array}{l}\text { Eligibility of } \\
\text { contents }\end{array}$ & $\begin{array}{l}\text { - Have } 5 \text { lab work titles that have been } \\
\text { sequenced and according to Curriculum } 2013 \\
\text { and syllabus: (1) Explain the dissolution } \\
\text { difference of a substance; (2) Describing the } \\
\text { relationship solubility with the constant of } \\
\text { solubility product; (3) predict the occurrence of } \\
\text { sediment; (4) Explain the determination of the } \\
\text { constant of solubility product and the influence } \\
\text { of ion names; (5) Observing the nature of } \\
\text { hardly soluble salts. } \\
\text { - The scope of the material presented reflects the } \\
\text { substance of the substance contained in the KI } \\
\text { and KD. } \\
\text { - The material depth has been expanded. } \\
\text { Every Trial is a mini research project }\end{array}$ \\
\hline $\begin{array}{l}\text { Eligibility of } \\
\text { Language }\end{array}$ & $\begin{array}{l}\text { - Using the correct Indonesian rules in } \\
\text { accordance with EYD } \\
\text { - Using short sentences, clear, and simple, so } \\
\text { easy to understand learners }\end{array}$ \\
\hline $\begin{array}{l}\text { Eligibility of } \\
\text { presentation }\end{array}$ & $\begin{array}{l}\text { - A4 paper size. } \\
\text { - Front and back book cover is in sync. } \\
\text { - Background module using an attractive color. } \\
\text { - The completeness of the presentation of the } \\
\text { module includes: } \\
\text { - Table of contents } \\
\text { - Occupational Safety in Laboratory } \\
\text { - Symbol or security symbol in laboratory }\end{array}$ \\
\hline
\end{tabular}




\begin{tabular}{ll}
\hline - & SPU (Periodic System of Elements) \\
- & Materials needed in Experiment \\
- & Each Title Trial contains Indicators and \\
& Objectives \\
- & Bibliography \\
- & Loading a number of illustrations \\
- & Loading glossary \\
- & Loading index list \\
- & Loading problems about solubility and \\
& solubility product (Ksp) \\
- Consistency in writing alphabet letters \\
- Layout or layout of drawings and writing in \\
- accordance with the proportion of objects \\
graffity \\
- life. \\
- MSDS mading illustrations, examples in everyday \\
are positioned in the front. \\
Solubility and solubility product (Ksp) loaded \\
- before \\
Glossary Glossary, index list, and SPU \\
published on the last page
\end{tabular}

\section{Implementation Of The Module Chemistry Developed}

\subsection{Learning Outcomes}

Percent gain of the experimental group 1 is higher than the percent gain of the experimental group 2, with a ratio of $88 \%$ to $80 \%$, thus the difference in gain of experiment group 1 learning result with experiment group 2 by $8 \%$. By testing "t test" of one party at ( $\alpha=$ $0.05)$, tcount is bigger than ttable $(6.4>1.67)$. This proves that the module chemistry that has been developed in the criteria are very good according to BSNP standard and are suitable for use in SMA

\subsection{Student Activity}

Student performance activity is one indicator that must exist in the practicum process because it influences student learning outcomes. Student activity data is obtained during the practicum, when students do the lab work on Solubility material and solubility (Ksp) results. Assessment of student activities was carried out by 3 observers, where observer I observed groups 1 and group 2 observer II observed group 3 and group 4, observer III observed groups 5 and groups 6 . Activities observed were student activities related to practicums that were not independent of psychomotor rubric, including laboratory clothes, work readiness, systematics, 
skills, curiosity, using tools, cleanliness, work results, and observational data Average values of each aspect of the experiment group 1 and experiment group 2 activities (performance) are presented as in the following figure 5.2.

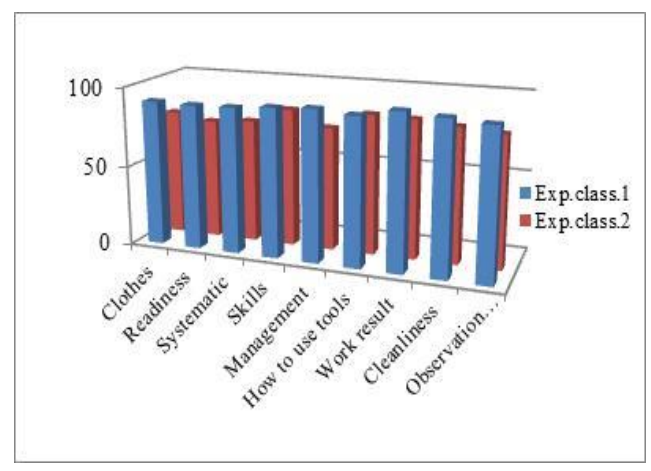

Fig 5.2. Student activity

From Figure 5.2. can be seen the average value of the performance aspects of 36 students in the experiment group 1 was obtained: completenes aspects of clothes 90,76 ; work readiness 90,19; skills 92,59; use of tools 91,67 ; management 93,78; cleanliness 94,44; work results 96,30 ; and observation data 92,59 , each in very competent criteria. The average performance aspect for 36 students of experiment group 2 was obtained: aspects of completeness for clothes for practicum suits 78.70; work readiness 78.70; systematic 76,90; management 76,77 all in the criteria are quite competent, and for the skill aspect 86,11 ; use of tools 87.65; cleanliness 83,75; work result 86,11; and observation data 81,48 , each in competent criteria. Overall, it can be seen that the performance aspects of experiment group 1 are very competent, while the experiment group 2 are competent and quite competent.

The activity value of students in experimental group 1 and 2 is presented in the following table 4

Table 4.StudentsActivity Scores in the Experimental Group 1 and 2

\begin{tabular}{cccc}
\hline No & Type of Data & Exp. Group 1 & \multicolumn{2}{c}{ Exp.Group } \\
\hline 1 & Number of & 36 & 36 \\
2 & Students & 85.19 & 62.96 \\
3 & Highest Value & 96.30 & 88.89 \\
4 & Average & 90.84 & 82,30 \\
\hline
\end{tabular}

From Table 4, the mean activity (grade) of the experimental class students using the module chemistry that has been developed in the Solubility and solubility product (Ksp) materials was higher than experiment group 2 using the teaching materials provided by the school. In the experiment group 1 the average score of activity of students is 90.84 with highly competent criteria and the average value of activity of experiment group 2 is 82.30 with competent criteria. 
The activity diagram of students during the chemical practice of the subject matter Solubility and solubility results (Ksp) inexperiment group 1 and 2 is as in Figure 5.3 below.

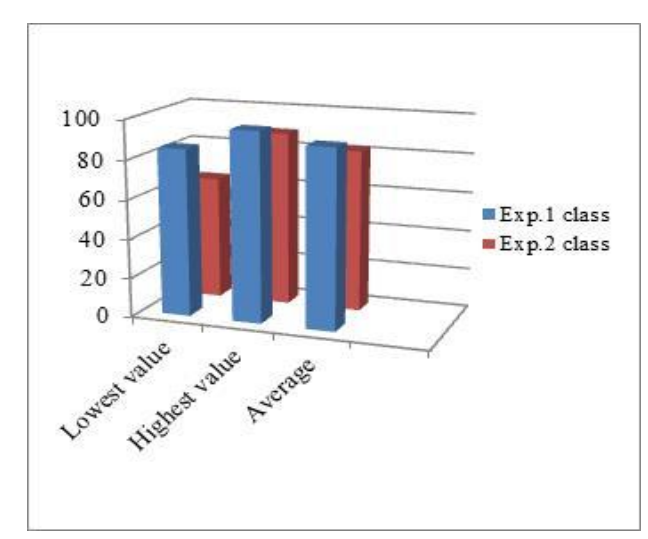

Fig 5.3. Activity Scores of the Exp. Group 1 and 2.

\section{Conclusion}

The XI class high school chemistry practicum guidance module from publishers (A), (B), and (C) circulating in the city of medan needs to be innovated and developed in the form of project-based innovation that integrates practicum and character internalization according to the 2013 curriculum. Module innovative project-based chemistry practicum on solubility material and the results of the solubility [Ksp] of the development results have been in accordance with bsnp standards. Student chemistry learning outcomes through the implementation of project-based chemistry practical guides developed in solubility material and solubility [Ksp] higher than the reference of student hand books.the psiomotoric and affective values of students who carry out the practicum using a project-based practicum guide that is developed higher than the reference of the student hand books.

\section{Recommendation}

TItrecommends that high school teachers shouldcarry out teaching and learning chemistry material integratedwith lab experiment sand character based on the 2013 curriculum, so that the learning process based on student-centered and they will be more proactive in studying chemistry and will be able to have a better understanding the material being taught.Chemistry teachers should betrained to implement the innovative project-based guided modules developed. It is also expected to carry outin depth research on the chemical practicum guided books for grades X, XI, and XII of senior high schoolsthat met the BSNP criteria. 
Acknowledgement. I would like to thank to the Directorate of Research and Community Service (DRPM) of the Directorate General of Strengthening Research and Development of the Ministry of Research Technology and Higher Education, for the financial assistance provided to finish the research properly. I would like also to thank to the School principal of Senior High School 14 Medan for her assistance in providing the location of the study, to the chemistry teachersof the Senior High School 14 Medan and the chemistry leturersof Unimed for theirwillingness to validate the practicum guided booksdeveloped. Hopefully the projectbased innovative chemistry practicum guided bookwhich met the BSNP standards can be used in high schools in Medan Indonesia.

\section{References}

[1]Anwar, I., Pengembangan Bahan Ajar Bahan Kuliah Online, Direktori UPI, Bandung, 2010,

[2]Chiang, C.L., Lee, H., The Effect of Project Based Learning on Learning Motivation and Problem Solving Ability of Vocational High School Students, International Journal of Information and Education Technology, 6(9): 709-712, 2016.

[3]Kalek, A. A, dan Lee, A., Aplication of project-based-learning in students, engagement in malaysian studies and english language, Journal of interdisciplinary Research in Education, Vol.2 No.1.p.3746, 2012.

[4]Robinson, Jill K., Project-Based Learning: Improving Student Engagement and Performance in The Laboratory, Anal Bional Chem, 405: 7-13, 2013,

[5]Sugiyono, Metode Penelitian Pendidikan (Pendekatan Kuantitatif, Kualitatif, dan R and D), Alfabeta, Bandung, 2010,

[6]Saksri Supasorn, Laorthip Kamsai, Vinich Promarak, Enhancement of learning achievement of organic chemistry using inquiry-based semi-small scale experiments (SSSEs), 5 th Science Direct World Conference on Educational Sciences, 2014.

[7]Shi-Jer Lou, Hui-Chen Lin, Ru-Chu, Kuo-Hung Tseng, Improving The Effectiveness Of Organic Chemistry Experiments Through Multimedia Teaching Materials For Junior High School Students, The Turkish Online Journal of Educational Technology - April 2012, volume 11 Issue 2, 2012.

[8]Tatli. Z and A. Ayas, Effect of Virtual Laboratory on Student's Achievment, Educational, 2013.

[9]Tuysuz, C., The Effect of the Virtual Laboratory on Students' Achievement and Attitude in Chemistry, International Online Technology and Socoety Journal, 16 (1): 159-170, 2010.

[10]Tatli. Z and A. Ayas, Virtual Chemistry Laboratory : Effect of Constructivist Learning Enverironmental, Turkish On Line Journal of Distance Education, 2012.

[11]Vega, Carlos., Jimenez Camilo., jorge Villalobos., A Scalable and Incremental Project-Based Learning Approach for CS1/CS2 Courses, Educ Inf Technol, 18: 309-329, 2013. 